\section{日本臨床外科学会滋賀県支部抄録 (第102回滋賀県外科医会)}

\author{
日 時: 平成24年12月 8 日（土） \\ 午後 1 時 20 分 午後 6 時 \\ 場＼cjkstart所：ピアザ淡海 県民交流センター
特別講演
座長 大津赤十字志賀病院
院長 馬場信雄 先生
「心藏血管外科手術の現状２012」 滋賀医科大学医学部附属病院 心臟血管外科 \\ 教授 浅井 徹 先生
}

\begin{abstract}
1 横隔膜に多発した小孔を認めた月経随伴性気胸の 1 例 市立長浜病院呼吸器外科

宮田＼cjkstart亮、河野朋哉、田久保康隆

症例は45歳, 女性. 2012年 4 月の健診で胸部異常影を指摘され, 前医で二次検診を受けた。胸部 CTで，右気胸，右胸水貯留，右 横隔膜直上の多発結節影を認め, 精查目的に当科紹介となった。 当院初診時の胸部レントゲン写真では気胸は寛解していたが, 外 来での経過観察中に胸部レントゲン写真で軽度の気胸の増悪, 寛 解を認めた。また，月経時に呼吸困難が出現することから，月経 随伴性気胸と診断され，8月下旬に手術を行った，中葉の縦隔面 に小さな bullaを認めた。 また, 横隔膜腱様部に肝臓が視認でき るほどの小孔を多数認めた，術前の CT で認めた右横隔膜直上の 多発結節影は, 肝臓がこの小孔を通って胸腔内に押し出されてい たことによってできていたものと考えられた，横隔膜腱膜部は自 動縫合器を用いて部分切除し, bullaは切除した。病理所見では 横隔膜, bullaのいずれの標本にも子宮内膜組織を認めた．若干 の文献的考察を含め報告する。
\end{abstract}

\section{2 緊急手術を行った開放性外傷性気胸の一例} 独立行政法人国立病院機構滋賀病院呼吸器外科 上田桂子、尾㠃良智、藤田珧也、井上修平 胸部外傷では迅速かつ適切な初期治療を施すことが求められる。 今回、自動草刈り機による鋭的胸部外傷で開放性気胸に至り緊急 手術を施行し一例を経験した。症例は70歳代男性。2012年 8 月初 旬、自動草刈り機で農作業中に過って転倒し回転刃で右側胸部と 左膝を負傷し当院へ救急搬送された。右側胸部に $25 \mathrm{~cm}$ の開放創 を認め肺が露出しており右第 9 肋骨離断および肺実質損傷を確認 した。開放創の仮閉鎖ののち緊急手術を施行。肺損傷部を自動綘 合機で部分切除した。術後経過は良好で術後 4 ケ月現在合併症な く外来通院中である。平成 22 年の農林水产省による統計では、農 作業中の事故の $16 \%$ が自動草刈り機によるものであるが、受傷部 位は四肢がほとんどであり体幹はまれである。自験例では肺実質 損傷に対して自動縫合器で損傷部を切除することで、污染創の除 去および肺瘦閉鎖を同時に得ることができた。
3 導入放射線化学療法後に気管支肺動脈形成を要した左 下葉肺癌の一例

大津赤十字病院呼吸器外科

豊洋次郎、片倉浩理、山中 晃

局所進行肺癌において外科的切除の意義は大きい。今回我々は、 大動脈浸潤が疑われた左下葉扁平上皮肺癌 cT 4 N 1 M 0 に対し て術前導入放射線化学療法 (CBDCA+PTX : 2 コース、40Gy) を施行し、外科的切除を行った 1 例を経験した。大動脈は外膜に て切除可能であったが、A 6 中枢への浸潤を認め、肺動脈中枢 taping 後にA 6 の中枢をクランプ、肺動脈を切離し、断端を 5 0プロリンにて縫合した。また、下葉気管支への浸潤に対しては、 wide wedgeで切離し、3-0 PDSにて縫合した。術後病理結果 では、pT 4 N 0 M 0 （大動脈外膜浸潤）であった。手術手技を供 覧する。

\section{4 腹痛で発症した左上腹部腫瘤の 1 例} 近江八幡市立総合医療センター外科1、同小児外科 2 伊佐怜子 ${ }^{1}$ 、秋岡清一 1 、原田俊平 1 、奥川 郁 1 、中野且敬 1 、大坂 芳夫 ${ }^{1}$ 、土屋邦之 1 、迫 裕孝 1 、田中智子 ${ }^{2}$

症例は36歳、男性、数日前より嘔吐、腹痛あり腹痛が増強したた めに近医より紹介となり救急外来を受診し、CTにて拡張した小 腸像と左上腹部に $15 \times 9 \mathrm{~cm}$ の巨大な腫瘤を指摘された。画像上 に大網捻転も疑われたが、腹痛は受診時には軽快しており腫瘤も 巨大であったために大網肉腫などの腫瘍性病変を疑い、翌日に全 身麻酔下に開腹手術を実施した。左上腹部に一塊となった暗紫色 の大網腫瘤を授動し、大網捻転であることを確認し大網切除を実 施した。大網は捻転の原因となる癒着もなく特発性大網捻転であ った。術前のCT、MRIにて大網捻転が疑われたが、腹痛が軽快 消失しており嘔吐や腹痛の原因がイレウス症状のためと疑ったこ とや、腫瘤が非常に巨大であったが臨床所見がそしかったことよ り悪性腫瘍を疑い、待機的に開腹手術で大網腫瘍の摘出を実施し た。大網捻転は術前にCTなどで診断され腹胿鏡下手術がされる ことも多いとされるが、大網腫瘍と鑑別を要した巨大な大網捻転 の 1 例を経験した。

5 胃軸捻転症を伴った成人横隔膜裂孔ヘルニアの 1 例 大津赤十字病院外科 阿部由督、中村直人、伊藤 孝、松林 潤、余語覚匡、花本浩一、 鬼頭祥悟、浦 克明、平良 薰、大江秀明、吉川 明、石上俊一、 土井隆一郎

症例は61歳女性。以前より CTで横隔膜ヘルニアの所見を認めて いたが、食事摂取不良と嘔吐をきたし、手術目的に当院へ紹介と なった。紹介前日に吐血をきたし、転院後に上部内視鏡検査を施 行した。明らかな出血源は認めなかったが、胃粘膜全体に発赤を 認め、胃底部が食道裂孔近傍より捻じれるように突出していた。 腹部ダイナミック CTでは、左肺背側に大網と胃全体におよぶ脱 出を認めた。胃透視では、大部分が胸腔内に脱出しており、Upside downの所見を示した。術中所見としては食道裂孔の $1 \mathrm{~cm}$ 左側、横隔膜左脚より外側にヘルニア門を認めた。大網がへルニ ア門周囲に癒着しており、胃は体部まで脱出していた。胃とへル ニア門周囲の癒着を剥離すると比較的容易に腹腔内へと還納でき た。閉鎖法は横隔膜縺縮術を選択した。

今回われわれは胃軸捻転症を伴った横隔膜傍裂孔へルニアを経験 したので文献的考察を交えて報告する。 
6 S 状結腸間膜窝ヘルニアの 1 例

滋賀県立成人病センター外科

木田裕也、尾川諒太郎、本庄真彦、宇野伊津美、中村直彦、中川 淳、矢澤武史、山本道宏、川村純一郎、原田英樹、山本秀和、四 元文明、財間正純

症例は63歳、男性。2011年10月突然の腹痛、嘔吐認め、近医受診 し腸閉塞の診断にて当院救急搬送となった。腹部 CTにてS 状結 腸背側に拡張した浮腫状の小腸や、closed loopの所見が認めら れ S 状結腸間膜に関連した内ヘルニアによるイレウスを疑った。 イレウスチューブ抻入後も症状軽快認めず手術の方針となった。 回盲部から約 $160 \mathrm{~cm}$ 口側の小腸が、S 状結腸間膜癒合不全部位に 嵌入しており、S 状結腸間膜窩へルニアの所見であった。嵌入腸 管に $1 \mathrm{~mm}$ 程度の穿孔部位を認め、嵌頓を整復、腸管切除、ヘル ニア門縫縮閉鎖を行った。S状結腸間膜に関連する内ヘルニアは 稀な疾患であり、若干の文献的考察を加え報告する。

\section{7 側方前方痔瘦に対する手術術式の検討}

はえうち診療所

○生内一夫

痔瘦に対する手術は根治性のみならず、特に側方前方痔瘦におい ては肛門機能の温存に十分配慮して行う必要があります。今回、 側方前方痔瘦に対する手術成績を検討したので報告いたします。 痔瘦手術症例74例中、側方前方痔瘦25例で、これらに対して開放 術式 1 例、くり抜き法 5 例、ゴムシートン法13例、クシャーラ. スートラを用いたシートン法 6 例が行われました。その内くり抜 き法で非治癒 2 例、再発 1 例を、ゴムシートン法で 2 例の再発を 認めました。一般的に括約筋温存手術の再発率は高く、高度な技 術を要するため、一般外科医が行う場合、根治性と機能温存を考 え、シートン法を用いた術式を考慮すべきと考えられました。今 後、材料の改良や新しい手術法の開発に期待したいところであり ます。

\section{TS- 1 で診断し得た退形成性膵管癌の 1 例} 大津赤十字病院外科

鬼頭祥悟、伊藤 孝、中村直人、松林 潤、余語覚匡、花本浩一、 浦 克明、平良 薰、大江秀明、吉川 明、石上俊一土井隆一 郎

症例は71歳の男性。血糖コントロール不良で他院から紹介となっ た。腹部造影 CTで主膵管の拡張認め、動脈相で膵頭部に多血性 の腫瘍を認めた。腹部超音波検査は膵頭部に $14 \mathrm{~mm}$ 大の低エコー 領域を認めた。ERCPにおいて主膵管の途絶と末梢膵管の拡張を 認め、膵液細胞診でclass V の診断を得た。膵頭部癌と診断し、 幽門輪温存膵頭十二指腸切除術を施行した。術後病理検査の HE 染色所見で類骨の産生と破骨細胞様の巨細胞を多数認めた。免疫 染色ではCD68と vimentin染色が陽性であった。破骨細胞型退形 成性萃管癌と診断した。退形成性膵管癌は全膵癌のうち $0.18 \%$ と 非常に稀であり、進行が早いものが多く、早期で発見された例は 少ない。本症例は腫瘍径 $9 \mathrm{~mm}$ の TS 1 で診断された退形成性膵 管癌である。このような報告は過去に 3 例のみであり、文献的考 察を加えて報告する。
9 肝外門脈瘤の 1 例

市立長浜病院外科

矢田善弘、村田 徹、花木宏治、三瀬昌宏、東出俊一、神田雄史、 野田秀樹

症例は85歳の女性。既往歴は高脂血症、高血圧症、狭心症、多発 性腎囊胞があり、肝硬変など肝疾患なし。2012年 6 月貧血の精查 にて胃癌を指摘され、当院紹介となった。術前 CTおよび腹部超 音波検査にて上腸間膜静脈脾静脈合流部近傍に約 $2 \mathrm{~cm}$ の肝外門 脈瘤を指摘された。カラードップラでは紡錘状の門脈瘤に渦状の 血流を認めた。2012年10月 LADG \& D $1+\beta$ を施行中、腹腔鏡で 確認し、現在経過観察中である。門脈瘤は1956年に最初に報告さ れ、門脈の一部が囊状または紡錘状に拡張した疾患で、稀な疾患 である。門脈瘤は発生する部位により、肝内門脈瘤と肝外門脈瘤 に分類される。特に肝外門脈瘤は稀である。今回、私たちは、胃 癌術前検查にて偶然発見された肝外門脈瘤を経験したので若干の 文献的考察を加えて報告する。

\section{0 当院における単孔式腹腔鏡下胆囊摘出術}

大津市民病院外科

加納正人、山本高正、橘強、中右雅之、洲崎 聡、光吉 明、 柳橋 健

当院では、2009年10月より単孔式腹腔鏡下胆囊摘出術 (SILC) を導入し手技の工夫を行ってきた。2011年 4 月より $\mathrm{E} ・ \mathrm{Z}$ アクセ スを用いている。鉗子などの干渉を低隇するために円筒に沿って 刺入部を配置し、助手用の把持針子も挿入している。術者左手と 助手の銝子は直接刺入することによってポート使用数を 2 本に減 らし、ポートの干渉とランニングコストを抑えている。2012年10 月末までにSILCを116例施行し、うち82例を現法で行った。2011 年11月からの 1 年間の待機的腹㒄鏡下胆摘術のうち $84 \%$ SILC で行い、平均手術時間は89.2分、出血量は少量、術後平均在院日 数は2.6日であった。合併症は、術後 1 日目に38度以上の発熱を 来した 1 例であった。SILCは従来の腹腔鏡下胆囊摘出術に代わ り胆囊摘出術の標準となるとみられるが、手技の改良が急速に進 みつつあり、標準化と安全性を高めていく努力が必要である。

11 当院における単孔式腹腔鏡下胆囊摘出術の変遷と現状 公立甲賀病院外科

山元俊行、龍見謙太郎、池田房夫、岡本正吾、沖野 孝、井田 健

良性胆囊病変には腹腔鏡下胆囊摘出術 $(\mathrm{Lap}-\mathrm{C})$ が第一選択術式 であるが、近年単孔式腹胿鏡下胆囊摘出術（TANKO-C）が導入 され適応が拡がりつつある。当院においても2011年 7 月より TANKO-Cを導入している。そこで、TANKO-Cの変遷と現状、 安全性について検討した。【対象】2011年 4 月から2012年11月ま でに施行したTANKO-C 27例と Lap-C 32例を対象とした。【結 果】年齢、男女比、手術時間、出血量、在院日数において両群間 に有為差は認めなかった。【考察】 TANKO-CはLap-Cに比べ、 整容性に優れるものの、鉗子同士の干渉や奥行きの把握が困難な どの欠点がある。しかしながら両群間の比較検討項目で有為差は 認めないことから、症例を積み重ね、適切に症例を選択すれば、 Lap-C と同様、安全に施行することが可能と考えられた。 
12 結核性腹膜炎の 1 例

済生会滋賀県病院外科

木内 純、藤田悠司、森田 翠、梅原誠司、中島 晋、福田賢一 郎、藤山准真、増山 守

肺外結核の一種である結核性腹膜炎は全結核の $0.04 \sim 0.6 \%$ 占め るにすぎない極めてまれな疾患である。

腹水の性状分析で結核菌の存在を証明できない場合、確定診断 のため腹腔鏡あるいは開腹による生検がなされるのが一般的であ る。しかし実臨床では病理的確定診断を得た症例は少ないとされ ている。

今回われわれは癌性腹膜炎との鑑別を要し、病理組織学的診断 を得られず、審查腹垫鏡で結核性腹膜炎と診断・加療した症例を 経験したので報告する。

$13 \mathrm{~S}$ 状結腸癌術後偽膜性腸炎により重症化したと思われ る虚血性腸炎の 1 例

彦根市立病院外科

大石賢斉、平田 渉、小松原隆司、安田誠一、李 正煜、寺村康 史、赤松 信 症例は70歳台男性。2012年 4 月頃より排便困難感·体重減少あり。 下部消化管内視鏡検查にてS 状結腸癌 type 2 , tub 1, Group 5 を認めた。 8 月、腹腔鏡補助下にIMA 根部処理による D 3 郭清 を伴うS 状結腸切除術を施行した。術後発熱・下痢・イレウスが あったが自然軽快し、第13病日に軽快退院した。退院後 6 日目に 偽膜と考えられる管腔状膜様構造物の排泄を認めた。その後吻合 部口側に高度の狭窄病変を認め、再手術を要した。

術後腸管虚血が偽膜性腸炎の危険因子となり偽膜性腸炎を発症 し、これが虚血性腸炎の腸管側因子として作用して腸管虚血が助 長され、虚血性腸炎が重症化して高度の腸管狭窄が生じたと考え られた。

今回我々はS 状結腸癌術後偽膜性腸炎により重症化したと思われ る虚血性腸炎の 1 例を経験した。管腔構造を維持した偽膜を排泄 した症例報告はなく、非常に興味深い症例であると考え、若干の 文献的考察を加え報告する。

14 Pulmonary tumor thrombotic microangiopathy を発 症し短期間で死亡した乳癌の 1 例

長浜赤十字病院外科

中川梨恵、金井俊平、北村美奈、長門 優、谷口正展、中村一郎、 中村誠昌、川口 晃、下松谷匠、丸橋和弘

症例は40代女性。多発転移を伴う左乳癌に対し、ホルモン療法、 化学療法を施行していた。治療中に労作時呼吸困難と全身倦怠感 を訴え、入院となった。血液検査では貧血と血小板減少を認め、 胸部 CTでは肺動脈や右心室の拡大など右心負荷所見を認めた が、肺動脈内の造影欠損像は認めなかった。点滴、輸血により一 時は自覚症状が改善したが入院 6 日目より突然呼吸困難が増悪し た。酸素投与を行うも動脈血液ガスでは著しい低酸素血症を認め、 血液検查ではDIC、多臟器不全を呈していた。肺血流シンチグラ フィでは肺末梢の多発血流欠損影を認めた。呼吸不全の進行によ り、入院 8 日目に死亡した。剖検は施行できなかったが、経過と 画像所見より Pulmonary tumor thrombotic microangiopathy (PTTM) と診断した。担癌患者の呼吸困難が生じた場合、早期 より PTTMを疑って精査、治療を行うことが必要である。
15 温熱化学療法後に発症した被囊性腹膜硬化症の検討 草津総合病院消化器外科

高尾信行、小座本雄軌、一瀬真澄、戸川 剛、水本明良、平野正 満

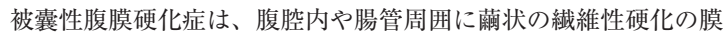
形成を来す疾患で、腹膜透析に伴う合併症として知られている。 我々は2008年 1 月から2011年12月までに270例（内腹腔鏡下施行 例が53例）の温熱化学療法を施行した。腹膜偽粘液腫146例、胃 癌48例、直腸結腸癌21例、虫垂癌15例、その他40例であった。同 治療 $\left(42^{\circ} \mathrm{C} / 60\right.$ 分/MMC $\left.20 \mathrm{mg} / \mathrm{CDDP} 100 \mathrm{mg}\right)$ 後に発症した被囊 性腹膜硬化症 4 例を経験した。 4 例の原疾患は、腹膜偽粘液腫 3 例、胃癌 1 例であり、温熱化学療法の開腹時施行例 2 例、腹腔鏡 下施行例 1 例（術後に腹腔ポートから腹腔内化学療法を 6 回施 行)、腹望鏡下と開腹時の 2 回施行例 1 例であった。 4 例のうち 3 例がイレウスを合併し、術前本症の疑いと診断されたものは 1 例であった。原因として手術の浸襲、腹腔内化学療法の可能性が 考えられた。 